\title{
Pengaruh Media Sosial Terhadap Keputusan Pembelian Di Toko Kaos Nias Gunungsitoli
}

\section{Maria Magdalena Bate'e}

Sekolah Tinggi Ilmu Ekonomi Pembangunan Nasional

maria.batee82@gmail.com

\begin{abstract}
Abstrak
Media sosial merupakan suatu wadah yang sangat efektif dalam kegiatan pemasaran, meskipun awalnya media sosial hanya digunakan untuk bersosialisasi dengan kerabat maupun keluarga namun seiring dengan perkembangan zaman media sosial dimanfaatkan oleh perusahaan besar atau kecil untuk kegiatan pemasaran. Penelitian ini bertujuan untuk mengetahui pengaruh media sosial terhadap keputusan pembelian di Toko Kaos Nias Gunungsitoli. Populasi dalam penelitian ini adalah konsumen Toko Kaos Nias, sedangkan sampel berjumlah 24 responden. Penelitian ini merupakan penelitian kuantitatif. Untuk variabel dependen (Y) dari penelitian ini adalah keputusan pembelian, untuk variabel independen (X) adalah media sosial. Hasil penelitian ini menunjukkan bahwa: Ada pengaruh media sosial terhadap keputusan pembelian. Penelitian ini menyarankan pengelola toko Kaos Nias melakukan pelayanan prima dalam melayani kebutuhan konsumen dan mempertahankan respon konsumen pada kegiatan pemasarannya serta terus melakukan promosi dengan menggunakan media sosial.
\end{abstract}

Kata Kunci Media Sosial, Keputusan Pembelian

\section{PENDAHULUAN}

Negara Indonesia seperti yang kita ketahui merupakan negara berkembang, dapat dilihat pada era globalisasi ini dunia usaha telah memasuki persaingan yang sangat ketat. Persaingan ini muncul seiring dengan perkembangan teknologi yang terus semakin canggih, mendorong berbagai macam perubahan sistem di dunia, baik secara langsung maupun tidak langsung. Dalam dunia bisnis perubahan sistem seperti, sistem dalam perdagangan, pemasaran, cara bertransaksi, dan penyampaian informasi terus akan berubah.

Di negara Indonesia sendiri pengguna internet mengalami peningkatan jumlah dari tahun ke tahunnya dan menurut proyeksi dari APJII (Asosiasi Penyelenggaraan Jasa Internet Indonesia) jumlah pengguna terus meningkat seperti yang digambarkan di bawah ini :

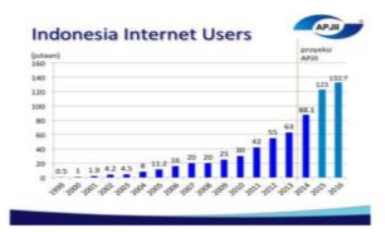

Gambar 1 Data Jumlah Pengguna Internet di Indonesia 
Menurut Kotler (2015: 10), "adanya teknologi yang canggih dengan jaringan internet memudahkan interaksi secara langsung antara konsumen dan pelaku bisnis". Apapun bisa dilakukan baik sekedar mencari informasi ataupun menjalankan bisnis. Hal ini sesuai dengan perilaku para penjual yang memanfaatkan kecanggihan teknologi dan internet yang memasarkan atau mempromosikan produk - produk yang yang mereka jual melalui media sosial atau pun web marketing. Di mana media sosial dan web marketing ini membutuhkan teknologi dan jaringan untuk mengaksesnya.

Media sosial bukanlah media yang asing lagi bagi masyarakat Indonesia. Data terbaru dari we are social, sebuah agensi marketing social pada Januari 2017 lalu menunjukkan adanya 72 juta akun media sosial yang aktif di Indonesia. Data tersebut menunjukkan penggunaan media sosial yang terus berkembang di Indonesia dari waktu ke waktu. Sosial media sejatinya memang sebagai media soasialisasi dan interaksi, serta menarik orang lain untuk melihat dan mengunjungi tautan yang berisi informasi mengenai produk, serta bisa juga dijadikan sebagai media pemasaran yang paling mudah dan murah. "Hal inilah yang akhirnya menarik para pelaku usaha juga digunakan sebagai alat pemasaran interaktif, pelayanan, membangun komunikasi dengan pelanggan dan calon pelanggan, serta sebagai alat untuk menjual dan membeli produk secara online" (Morrison, $2007: 30$ ).

Ada beberapa hal yang membuat sistem penjualan di Indonesia berubah. Dulunya menggunakan sistem offline namun dimasa perkembangan teknologi dan internet yang begitu cepat, memaksa para penjual harus mengikuti perkembangan zaman dengan merubah sistem penjualannya menjadi sistem online seperti penjualan melalui media sosial ini. Para penjual lebih memilih media sosial ketimbang media lainnya karena pengguna media sosial di Indonesia sangat banyak. Hal ini membuat penjual dengan mudah memasarkan dagangannya. Disisi lain para konsumen juga mendapatkan kenyamanan dan kemudahan berbelanja melalui media sosial, konsumen dapat menghemat waktu dan ruang saat berbelanja, konsumen dengan mudah mencari dan membandingkan barang yang dia inginkan.

Riset yang dilakukan Nielsen pada tahun 2016 lalu melaporkan, 53 persen responden menyatakan kesehariannya dalam mengakses media digital dan media sosial untuk menemukan produk-produk pilihannya. Survei itu dilakukan di Jakarta, Surabaya, Bandung, Semarang, Medan, dan Makassar dengan kisaran usia responden 18 tahun sampai 55 tahun.

Pemasaran melalui media sosial ini disebut social media marketing. Berdasar Optima Web, social media marketing adalah upaya pemasaran online dengan menciptakan visibilitas, eksistensi dan keberadaan sebuah situs web pada sosial media network (jaringan media sosial) seperti Facebook, Twitter, Digg, Web 2.0 . Singkatnya "social media marketing adalah sebuah kelompok aplikasi berbasis internet yang membangun Web 2.0 ideologi dan teknologi dan yang memungkinkan penciptaan dan pertukaran user generated content" ( Andreas Kaplan dan Michael Haenlein $2010: 61)$

Hasil survei yang dilakukan oleh Asosiasi Penyelenggara Jasa Internet Indonesia (APJII) pada 2016 menunjukkan konsumen Indonesia memutuskan berbelanja lewat media sosial ketimbang situs belanja. Ini adalah salah satu ciri dari keputusan pembelian di mana Schiffman dan Kanuk (2000:437) beranggapan bahwa "keputusan pembelian merupakan keputusan seseorang di mana dia memilih salah satu dari beberapa alternatif 
pilihan yang ada". Sebanyak $82,2 \%$ atau 62 juta orang Indonesia mengaku lebih sering mengklik online shop yang dikenal di Facebook dan Instagram.

Instagram merupakan aplikasi photo-sharing yang sedang digandrungi belakangan ini. Kelebihan Instagram sebagai alat pemasaran adalah Instagram dapat menyampaikan pesan dari suatu brand melalui foto/gambar atau video berdurasi 15 detik. Dikemukakan oleh Kotler- Keller (2008:06), bahwa pemasaran adalah : "Suatu proses sosial yang di dalamnya individu dan kelompok mendapatkan apa yang mereka butuhkan dan inginkan dengan menciptakan, menawarkan, dan secara bebas mempertukarkan produk yang bernilai dengan pihak lain". Kini era sosial media secara pelan namun pasti telah 'memaksa' banyak perusahaan mengubah cara mereka berkomunikasi. Maraknya penggunaan sosial media misal: Facebook, Instagram dan forum komunikasi sosial media yang lain mau tidak mau memaksa perusahaan meningkatkan model ber-komunikasi. Meskipun Facebook masih menjadi media sosial dengan pengguna dan aktivasi terbesar di dunia, tapi Instagram mampu menawarkan hal yang lebih dari itu. Hasil studi Forrester Research menunjukkan bahwa popularitas Instagram sebagai platform pemasaran melebihi kepopuleran Facebook. Forbes bahkan menggambarkan Instagram sebagai perangkat penjualan yang sangat kuat. Instagram sebagai media visual dapat memancing perhatian, apalagi untuk usaha atau brand yang berbentuk fisik.

Hal inilah yang dimanfaatkan Toko Kaos Nias dalam memasarkan produknya berupa kaos yang dapat disablon dengan berbagai karakter daerah Nias dan dapat juga disesuaikan dengan keinginan pelanggan. Toko Kaos Nias mempromosikan produknya melalui media sosial seperti Instagram dan Facebook.

Toko Kaos Nias yang memiliki toko fisik di Pasar Ya'ahowu diketahui mempunyai pengikut Instagram yang sangat banyak, sehingga hal ini memudahkannya dalam memasarkan produk. Terlebih fitur instagram yang memuat gambar atau video berdurasi singkat sehingga fitur digunakan untuk memuat display produk yang dipasarkan.

Sama halnya dengan Instagram, Toko Kaos Nias juga menggunakan Facebook sebagai wadah pemasarannya. Kelebihan dari Facebook ini yaitu apabila ada pengikut yang tertarik dengan produk yang ditawarkan kemudian membagikannya maka seluruh temannya akan dapat melihat produk yang ditawarkan Toko Kaos Nias, sekalipun mereka tidak mengikuti page atau halaman Facebook Toko Kaos Nias.

\section{LANDASAN TEORI}

\section{Pengertian Media Sosial}

Keller (2016: 34) mengungkapkan bahwa "media sosial adalah media yang digunakan oleh konsumen untuk berbagi teks, gambar, suara, dan video informasi baik dengan orang lain maupun perusahaan dan vice versa". Karakteristik umum yang dimiliki setiap media sosial yaitu adanya keterbukaan dialog antar para pengguna. Sosial media dapat dirubah oleh waktu dan diatur ulang oleh penciptanya, atau dalam beberapa situs tertentu, dapat diubah oleh suatu komunitas. Selain itu sosial media juga menyediakan dan membentuk cara baru dalam berkomunikasi. Seperti diketahui, sebelum muncul dan populernya media sosial, kebanyakan orang berkomuni kasi dengan cara SMS atau telpon lewat handphone. Namun sekarang dengan adanya media sosial, orang cenderung berkomunikasi lewat layanan obrolan (chat) atau berkirim pesan lewat layanan yang tersedia di media sosial. 
Menurut P.N. Howard dan M.R. Parks (2012: 21), "Media sosial adalah media yang terdiri atas tiga bagian, yaitu: Infrastruktur informasi dan alat yang digunakan untuk memproduksi dan mendistribusikan isi media yang berupa pesan-pesan pribadi, berita, gagasan, dan produkproduk budaya yang berbentuk digital. Kemudian yang memproduksi dn mengkonsumsi isi media dalam bentuk digital adalah individu, organisasi, dan industri."

Sosial media merupakan pergeseran penyebaran informasi dari mekanisme broadcast (one-to-many) menjadi mekanisme many-to-many. "Media sosial adalah konten berisi informasi yang dibuat oleh orang yang memanfaatkan teknologi penerbitan, sangat mudah diakses dan dimaksudkan untuk memfasilitasi komunikasi, pengaruh dan interaksi dengan sesama dan dengan khalayak umum" (Nasrullah, 2015: 6).

Dari beberapa pengertian media sosial di atas maka dapat disimpulkan bahwa media sosial merupakan alat promosi bisnis yang efektif karena dapat diakses oleh siapa saja, sehingga jaringan promosi bisa lebih luas.

\section{Jenis-Jenis Media Sosial}

Sampai saat ini ada banyak jenis media sosial yang digunakan oleh orang banyak. Namun peneliti dalam hal ini memfokuskan pada dua jenis media sosial yang sering digunakan yaitu:

a. Facebook

Facebook adalah sebuah layanan jejaring sosial berkantor pusat di Menlo Park, California, Amerika Serikat yang diluncurkan pada bulan Februari 2004. Hingga September 2012, Facebook memiliki lebih dari satu miliar pengguna aktif, lebih dari separuhnya menggunakan telepon genggam. Pengguna harus mendaftar sebelum dapat menggunakan situs ini. Setelah itu, pengguna dapat membuat profil pribadi, menambahkan pengguna lain sebagai teman, dan bertukar pesan, termasuk pemberitahuan otomatis ketika mereka memperbarui profilnya. Selain itu, pengguna dapat bergabung dengan grup pengguna dengan ketertarikan yang sama, diurutkan berdasarkan tempat kerja, sekolah atau perguruan tinggi, atau ciri khas lainnya, dan mengelompokkan teman-teman mereka ke dalam daftar seperti "Rekan Kerja" atau "Teman Dekat".

\section{b. Instagram}

Instagram adalah sebuah aplikasi berbagi foto dan video yang memungkinkan pengguna mengambil foto, mengambil video, menerapkan filter digital, dan membagikannya ke berbagai layanan jejaring sosial, termasuk milik Instagram sendiri. Satu fitur yang unik di Instagram adalah memotong foto menjadi bentuk persegi, sehingga terlihat seperti hasil kamera Kodak Instamatic dan polaroid. Hal ini berbeda dengan rasio aspek 4:3 yang umum digunakan oleh kamera pada peranti bergerak.

\section{Indikator Media Sosial}

Beberapa indikator-indikator media sosial, yaitu :

a. Kemudahan 
Ketika seseorang ingin berbelanja melalui media sosial, hal yang menjadi pertimbangan bagi pembeli online adalah faktor kemudahan penggunaan. Faktor kemudahan ini terkait dengan bagaimana operasional bertransaksi secara online. Biasanya calon pembeli akan mengalami kesulitan pada saat pertama kali bertransaksi online, dan cenderung mengurungkan niatnya karena faktor keamanan serta tidak tahu cara bertransaksi online. Dilain pihak, ada juga calon pembeli yang berinisiatif untuk mencoba karena telah mendapatkan informasi tentang cara bertransaksi online. Suatu website online shop yang baik adalah yang menyediakan petunjuk cara bertransaksi online, mulai dari cara pembayaran, dan fitur pengisian form pembelian. Kemudahan juga digunakan sebagai suatu tingkatan di mana seseorang percaya bahwa suatu teknologi dapat dengan mudah digunakan. Suatu situs online yang sering digunakan menunjukkan bahwa situs tersebut lebih dikenal, lebih mudah dioperasikan dan lebih mudah digunakan oleh para pengguna media sosial. Kemudahan dalam mencari informasi yang disajikan pada online shop sebaiknya mencakup informasi berkaitan dengan produk dan jasa yang ada pada online shop.

2. Kepercayaan

Hal yang menjadi pertimbangan seorang pembeli selanjutnya adalah apakah mereka percaya kepada website yang menyediakan online shop dan penjual online pada website tersebut. Kepercayaan pembeli terhadap website online shop terletak pada popularitas website online shop tersebut. Semakin popularitas suatu website, maka pembeli lebih yakin dan percaya terhadap reliabilitas website tersebut. Selanjutnya, kepercayaan pembeli terhadap penjual online terkait dengan keandalan penjual online dalam menjamin keamanan bertransaksi dan meyakinkan transaksi akan diproses setelah pembayaran dilakukan oleh pembeli. Keandalan ini terkait dengan keberadaan penjual online. Semakin berkembangnya teknologi, semakin berkembang pula modus penipuan berbasis teknologi pada online shop. Pada situs-situs online shop, tidak sedikit penjual online fiktif yang memasarkan produk fiktif juga. Seorang pembeli harus terlebih dahulu untuk mengecek keberadaan penjual online. Biasanya pada situs online shopping, situs akan menampilkan informasi tentang penjual-penjual yang "lapaknya" sering diakses oleh orang. Pembeli dapat memanfaatkan informasi ini ketika akan membeli online.

3. Kualitas Informasi

Kualitas informasi didefinisikan sebagai seberapa besar suatu informasi tentang produk dan jasa berguna dan relevan bagi pembeli online dalam memprediksi kualitas dan utilitas suatu produk dan jasa yang ditawarkan di Online Shop.

\section{Pengertian Keputusan Pembelian}

Menurut Lamb (2013 : 20) "Keputusan membeli yaitu salah satu komponen utama dari perilaku konsumen. Keputusan pembelian konsumen yaitu tahap demi tahap yg digunakan konsumen ketika membeli barang dan jasa". Pengertian lainnya "Keputusan pembelian yaitu sebuah pendekatan penyelesaian masalah pada kegiatan manusia untuk membeli suatu barang atau jasa dalam memenuhi keinginan dan kebutuhannya" (Swastha, 2015:34). Sedangkan menurut Kotler (2015 : 24), "keputusan pembelian adalah tindakan dari konsumen untuk mau membeli atau tidak terhadap produk". 
Dari beberapa pengertian keputusan pembelian tersebut dapat diambil kesimpulan keputusan pembelian adalah tindakan yang dilakukan oleh konsumen dalam memutuskan membeli barang ataupun jasa yang dibutuhkannya.

\section{Tahap-Tahap Pengambilan Keputusan}

Sebelum konsumen memutuskan untuk membeli, biasanya konsumen melalui beberapa tahap terlebih dahulu (Kotler, $2015: 25)$ yaitu :

a. Pengenalan masalah

Proses pembelian dimulai saat pembeli mengenali masalah atau kebutuhan, yang dipicu oleh rangsangan internal atau eksternal. Rangsangan internal misalnya dorongan memenuhi rasa lapar, haus dan seks yang mencapai ambang batas tertentu. Sedangkan rangsangan eksternal misalnya seseorang melewati toko kue dan melihat roti yang segar dan hangat sehingga terangsang rasa lapar.

b. Pencarian informasi

Konsumen yang terangsang kebutuhannya akan terdorong untuk mencari informasi yang lebih banyak. Sumber informasi konsumen yaitu:

Sumber pribadi

: keluarga, teman, tetangga dan kenalan.

Sumber komersial

Sumber publik

Sumber pengalaman

c. Evaluasi alternatif

Konsumen memiliki sikap beragam dalam memandang atribut yang relevan dan penting menurut manfaat yang mereka cari. Kumpulan keyakinan atas merek tertentu membentuk citra merek, yang disaring melalui dampak persepsi selektif, distorsi selektif dan ingatan selektif.

d. Keputusan pembelian

Dalam tahap evaluasi, para konsumen membentuk preferensi atas merek-merek yang ada di dalam kumpulan pilihan. Faktor sikap orang lain dan situasi yang tidak dapat diantisipasi yang dapat mengubah niat pembelian termasuk faktor-faktor penghambat pembelian. Dalam melaksanakan niat pembelian, konsumen dapat membuat lima sub-keputusan pembelian, yaitu: keputusan merek, keputusan pemasok, keputusan kuantitas, keputusan waktu dan keputusan metode pembayaran.

e. Perilaku pasca pembelian

Para pemasar harus memantau kepuasan pasca pembelian, tindakan pasca pembelian dan pemakaian produk pasca pembelian, yang tujuan utamanya adalah agar konsumen melakukan pembelian ulang.

\section{Faktor-Faktor Yang Mempengaruhi Keputusan Pembelian}

Menurut phillip Kotler (2015:27) perilaku pembelian konsumen dipengaruhi oleh empat faktor, diantaranya sebagai berikut:

1. Faktor Budaya

Budaya, sub budaya, dan kelas sosial sangat penting bagi perilaku pembelian. Budaya merupakan penentu keinginan dan perilaku paling dasar. Masingmasing sub budaya terdiri dari sejumlah sub-budaya yang lebih menampakkan identifikasi dan sosialisasi khusus bagi para anggotanya seperti kebangsaan, agama, kelompok, ras, dan wilayah geografis.

Pada dasarnya dalam sebuah tatanan kehidupan dalam bermasyarakat terdapat sebuah tingkatan (strata) sosial. Kelas sosial tidak hanya 
mencerminkan penghasilan, tetapi juga indikator lain seperti pekerjaan, pendidikan, perilaku dalam berbusana, cara bicara, rekreasi dan lain-lainya.

2. Faktor Sosial

Selain faktor budaya, perilaku pembelian konsumen juga dipengaruhi oleh faktor sosial diantaranya sebagai berikut:

- Kelompok acuan

Kelompok acuan dalam perilaku pembelian konsumen dapat diartikan sebagai kelompok yang yang dapat memberikan pengaruh secara langsung atau tidak langsung terhadap sikap atau perilaku seseorang tersebut.

- Keluarga

Dalam sebuah organisasi pembelian konsumen, keluarga dibedakan menjadi dua bagian. Pertama keluarga yang dikenal dengan istilah keluarga orientasi. Keluarga jenis ini terdiri dari orang tua dan saudara kandung seseorang yang dapat memberikan orientasi agama, politik dan ekonomi serta ambisi pribadi, harga diri dan cinta. Kedua, keluarga yang terdiri dari pasangan dan jumlah anak yang dimiliki seseorang. Keluarga jenis ini biasa dikenal dengan keluarga prokreasi.

- Peran dan status

Hal selanjutnya yang dapat menjadi faktor sosial yang dapat mempengaruhi perilaku pembelian seseorang adalah peran dan status mereka di dalam masyarakat. Semakin tinggi peran seseorang di dalam sebuah organisasi maka akan semakin tinggi pula status mereka dalam organisasi tersebut dan secara langsung dapat berdampak pada perilaku pembeliannya.

3. Pribadi

Keputusan pembelian juga dapat dipengaruhi oleh karakterisitik pribadi diantaranya usia dan tahap siklus hidup, pekerjaan, keadaan ekonomi, gaya hidup, serta kepribadian dan konsep-diri pembeli.

4. Psikologis

Terakhir, faktor yang dapat mempengaruhi keputusan pembelian konsumen adalah faktor psikologis. Faktor ini dipengaruhi oleh empat faktor utama diantaranya sebagai berikut:

- Motivasi

- Persepsi

- Pembelajaran

- Keyakinan dan Sikap

\section{METODOLOGI PENELITIAN}

Penelitian ini dilakukan bertujuan untuk mengetahui apakah media sosial berpengaruh pada keputusan pembelian pada Kaos Nias yang berada di Kota Gunungsitoli tepatnya di Pasar Ya'ahowu block C, lantai 2, nomor 05-06b. Jenis penelitian yang dilakukan dalam penelitian ini adalah jenis penelitian kuantitatif. Populasi dalam penelitian ini adalah konsumen Toko Kaos Nias yang menggunakan media sosial berjumlah 120 orang sedangkan pengambilan sampel dilakukan pendekatan menurut Arikunto (2015 : 93) apabila kurang dari 100 lebih baik diambil semua hingga penelitiannya merupakan penelitian populasi. Jika jumlah subjeknya besar dapat diambil antara $10-15 \%$ atau $20-55 \%$ atau lebih tergantung sedikit 
banyaknya dari : a) Kemampuan peneliti dilihat dari waktu, tenaga dan dana; b) Sempit luasnya wilayah pengamatan dari setiap subyek, karena hal ini menyangkut banyak sedikitnya dana; c) Besar kecilnya resiko yang ditanggung oleh peneliti untuk peneliti yang resikonya besar, jika sampelnya besar hasilnya baik. Oleh karena itu sampel dalam penelitian ini adalah $20 \%$ dari jumlah populasi yaitu 24 orang. Sedangkan teknik pengumpulan data dalam penelitian ini adalah dengan menggunakan kuisioner.

\section{HASIL PENELITIAN}

\section{Pengujian Alat Penelitian}

Setiap butir soal yang telah dijawab oleh responden selanjutnya diuji validitasnya. Validitas adalah suatu ukuran yang menunjukkan tingkat kevalidan sesuatu instrumen. Sebuah instrumen dikatakan valid apabila mampu mengukur apa yang diinginkan dan mengungkap data dari variabel yang diteliti secara tepat. Untuk menguji validitas item soal digunakan rumus korelasi yang dapat digunakan adalah yang dikemukakan oleh Pearson yang dikenal dengan rumus korelasi product moment sebagai berikut:

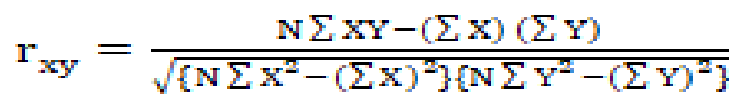

Untuk mengetahui dan menguji validitas, maka hasil rumus di atas disubstitusikan dengan mengkonsultasikan pada tabel harga kritik $\mathrm{r}$ product moment, dengan tingkat kepercayaan $95 \%$. Ketentuan pengujian validitas suatu instrumen diperoleh apabila $r_{x y}>$ $\mathrm{r}_{\text {tabel}}$, maka instrumen penelitian tersebut dinyatakan valid.

Adapun hasil perhitungan validitasnya adalah sebagai berikut :

Tabel 4.1 Pengujian Validitas Variabel X

\begin{tabular}{|c|c|c|c|}
\hline $\begin{array}{c}\text { No } \\
\text { Item }\end{array}$ & $\begin{array}{c}\text { Nilai } \mathbf{r} \\
\text { Hitung }\end{array}$ & $\begin{array}{c}\text { Nilai } \mathbf{r} \\
\text { Tabel }\end{array}$ & Keterangan \\
\hline 1 & 0,556 & 0,404 & Valid \\
\hline 2 & 0,432 & 0,404 & Valid \\
\hline 3 & 0,599 & 0,404 & Valid \\
\hline 4 & 0,425 & 0,404 & Valid \\
\hline 5 & 0,744 & 0,404 & Valid \\
\hline 6 & 0,616 & 0,404 & Valid \\
\hline 7 & 0,644 & 0,404 & Valid \\
\hline 8 & 0,538 & 0,404 & Valid \\
\hline 9 & 0,619 & 0,404 & Valid \\
\hline 10 & 0,442 & 0,404 & Valid \\
\hline
\end{tabular}

Sedangkan hasil perhitungan validitas untuk variabel Y adalah sebagai berikut :

Tabel 4.2 Pengujian Validitas Variabel Y 


\begin{tabular}{|c|c|c|c|}
\hline $\begin{array}{c}\text { No } \\
\text { Item }\end{array}$ & $\begin{array}{c}\text { Nilai r } \\
\text { Hitung }\end{array}$ & $\begin{array}{c}\text { Nilai r } \\
\text { Tabel }\end{array}$ & Keterangan \\
\hline 1 & 0,580 & 0,404 & Valid \\
\hline 2 & 0,470 & 0,404 & Valid \\
\hline 3 & 0,680 & 0,404 & Valid \\
\hline 4 & 0,442 & 0,404 & Valid \\
\hline 5 & 0,440 & 0,404 & Valid \\
\hline 6 & 0,413 & 0,404 & Valid \\
\hline
\end{tabular}

Berdasarkan tabel hasil perhitungan seluruh item soal untuk angket variabel $\mathrm{X}$ (Media Sosial) yang terdiri dari 10 item pertanyaan dan angket variabel Y (Keputusan Pembelian) yang terdiri atas 6 item pertanyaan sebagaimana yang tertera diatas, diperoleh hasil perhitungan seluruh validitas angket adalah $\mathrm{r}_{\text {hitung }}$ lebih besar dari nilai $r_{\text {tabel }}=0,404$ ( $r_{\text {hitung }}>r_{\text {tabel }}$ ), dengan demikian dapat dinyatakan bahwa seluruh item soal adalah valid.

Selanjutnya setiap instrumen pertanyaan juga diuji reliabilitasnya. Pengujian Reliabilitas dilakukan dengan metode belah dua, membelah item menjadi item ganjil dan genap dan mengkorelasikannya dengan menggunakan rumus korelasi product moment sebagai berikut:

$$
r_{x y}=\frac{N \sum X Y-\left(\sum X\right)\left(\sum Y\right)}{\sqrt{\left.\left\{N \sum X^{2}-\left(\sum X\right)^{2}\right\} N \sum Y^{2}-\left(\sum Y\right)^{2}\right\}}}
$$

Hasil dari rumus korelasi product moment tersebut selanjutnya disubsitusikan ke dalam rumus Spearman Brown yakni:

$$
\mathrm{r}_{\mathrm{ii}}=\frac{2 \cdot \mathrm{r}^{1 / 2} \mathrm{2}^{1 / 2}}{1+\mathrm{r}^{1 / 2} / 2^{1 / 2}}
$$

Dari hasil perhitungan yang telah dilakukan untuk variabel X (Media Sosial), diperoleh nilai Reliabilitas sebesar $r_{i i}=0,759$. Oleh karena itu, dengan jumlah $n=24$ pada tingkat kepercayaan $95 \%$ diperoleh nilai $r_{\text {tabel }}$ sebesar 0,404. Berdasarkan syarat uji Reliabilitas jika $r_{\text {hitung }}>r_{\text {tabel }}$ atau 0,759 $>0,404$ maka seluruh data angket item soal untuk variabel $X$ dinyatakan reliabel. Demikian pula setelah dilakukan perhitungan untuk variabel Y (Keputusan Pembelian), diperoleh nilai Reliabilitas sebesar $r_{i i}=0,515$. Oleh karena itu, dengan jumlah $\mathrm{n}=24$ pada tingkat kepercayaan 95\% diperoleh nilai $r_{\text {tabel }}$ sebesar 0,404. Berdasarkan syarat uji Reliabilitas jika $r_{\text {hitung }}>r_{\text {tabel }}$ atau 0,515 > 0,404 maka seluruh data angket item soal untuk variabel Y dinyatakan reliabel.

Untuk mengetahui apakah Media Sosial (variabel $X$ ) berpengaruh terhadap Keputusan Pembelian (variabel Y), maka terlebih dahulu dilakukan pengujian korelasi variabel $\mathrm{X}$ dan $\mathrm{Y}$ dengan menggunakan rumus korelasi product moment sebagai berikut:

$$
\mathrm{xy}=\frac{\mathrm{N} \Sigma \mathrm{XY}-(\Sigma \mathrm{X})(\Sigma \mathrm{Y})}{\sqrt{\left\{\mathrm{N} \Sigma \mathrm{X}^{2}-(\Sigma \mathrm{X})^{2}\right\}\left[\mathrm{N} \Sigma \mathrm{Y}^{2}-(\Sigma \mathrm{Y})^{2}\right\}}}
$$


Untuk memudahkan penulis dalam menghitung korelasi antara kedua variabel tersebut, maka diperlukan tabel penolong seperti tabel berikut ini.

Tabel 4.3

Tabel Penolong Untuk Menghitung Korelasi Antara Variabel X (Media Sosial) terhadap Variabel Y (Keputusan Pembelian)

\begin{tabular}{|c|c|c|c|c|}
\hline $\mathbf{X}$ & $\mathbf{Y}$ & $\mathbf{X}$ & Y & XY \\
\hline 35 & 22 & 1225 & 484 & 770 \\
\hline 29 & 18 & 841 & 324 & 522 \\
\hline 36 & 23 & 1296 & 529 & 828 \\
\hline 33 & 19 & 1089 & 361 & 627 \\
\hline 35 & 20 & 1225 & 400 & 700 \\
\hline 31 & 18 & 961 & 324 & 558 \\
\hline 35 & 24 & 1225 & 576 & 840 \\
\hline 38 & 15 & 1444 & 225 & 570 \\
\hline 29 & 21 & 841 & 441 & 609 \\
\hline 30 & 17 & 900 & 289 & 510 \\
\hline 27 & 17 & 729 & 289 & 459 \\
\hline 23 & 18 & 529 & 324 & 414 \\
\hline 23 & 17 & 529 & 289 & 391 \\
\hline 35 & 20 & 1225 & 400 & 700 \\
\hline 28 & 17 & 784 & 289 & 476 \\
\hline 27 & 15 & 729 & 225 & 405 \\
\hline 35 & 16 & 1225 & 256 & 560 \\
\hline 32 & 20 & 1024 & 400 & 640 \\
\hline 33 & 22 & 1089 & 484 & 726 \\
\hline 31 & 17 & 961 & 289 & 527 \\
\hline 34 & 23 & 1156 & 529 & 782 \\
\hline 34 & 19 & 1156 & 361 & 646 \\
\hline 35 & 19 & 1225 & 361 & 665 \\
\hline 37 & 20 & 1369 & 400 & 740 \\
\hline 765 & 457 & 24777 & 8849 & 14665 \\
\hline
\end{tabular}

Berdasarkan tabel di atas dengan data-data berikut: $\mathrm{n}=24, \sum \mathrm{X}=765, \sum \mathrm{Y}=457$ $\sum \mathrm{X}^{2}=24777, \sum \mathrm{Y}^{2}=8849, \sum \mathrm{XY}=14665$, maka langkah selanjutnya adalah kedua data tersebut dikorelasikan dengan rumus:

$$
\begin{aligned}
& \mathrm{xy}=\frac{\mathrm{N} \sum \mathrm{XY}-\left(\sum \mathrm{X}\right)(\Sigma \mathrm{Y})}{\sqrt{\left\{\mathrm{N} \Sigma \mathrm{X}^{2}-(\Sigma \mathrm{X})^{2}\right\}\left[\mathrm{N} \Sigma \mathrm{Y}^{2}-(\Sigma \mathrm{Y})^{2}\right\}}} \\
& \operatorname{rxy}=\frac{24 \times 14665-(765)(457)}{\sqrt{\left\{\left(24 \times 24777-(765)^{2}\right)\right\}\left\{\left(24 \times 8849-(457)^{2}\right)\right\}}}
\end{aligned}
$$




$$
\begin{aligned}
\operatorname{rxy} & =\frac{351960-349605}{\sqrt{\{(594648-585225)\}\{(212376-208849)\}}} \\
r x y & =\frac{2355}{\sqrt{[9423[3527]}} \\
r x y & =\frac{2355}{\sqrt{33234921}} \\
r x y & =\frac{2355}{5764,974} \\
r x y & =0,4085
\end{aligned}
$$

Dari hasil perhitungan di atas, diperoleh nilai korelasi antara variabel X (Media Sosial) dengan Variabel Y (Keputusan Pembelian) sebesar $r_{i i}=0,4085$. Ini berarti bahwa variabel X dan Y memiliki korelasi diman rii > rtabel atau 0,4085 > 0,404.

Untuk mengetahui kehandalan adanya pengaruh variabel yang satu dengan variabel lainnya, maka pengujian hipotesis perlu dilakukan dengan menggunakan rumus Uji Parsial t sebagai berikut:

$$
\begin{aligned}
\mathrm{t} & =\frac{r \sqrt{n-2}}{\sqrt{1-r^{2}}} \\
& =\frac{0,4085 \sqrt{24-2}}{\sqrt{1-(0,4085)^{2}}} \\
& =\frac{0,4085 \sqrt{22}}{\sqrt{1-0,1669}} \\
& =\frac{0,4085 x 4,69}{\sqrt{0,8331}} \\
& =\frac{1,9159}{0,9127} \\
\mathrm{t} & =2,0991
\end{aligned}
$$

Dari hasil perhitungan di atas, diperoleh nilai antara variabel X (Media Sosial) dengan Variabel Y (Keputusan Pembelian) sebesar $t=2,0991$. Dengan jumlah $n=24$ pada tingkat kepercayaan 95\% diperoleh nilai $t_{\text {tabel }}$ sebesar 2,0738. Berdasarkan ketentuan yang berlaku, jika $t_{\text {hitung }}>\mathrm{t}_{\text {tabel }}$ atau 2,0991> 2,0738 maka Ha ( Hipotesis Alternatif) diterima dan Ho ditolak. Dengan demikian dapat dinyatakan bahwa terdapat pengaruh Media Sosial terhadap Keputusan Pembelian di Toko Kaos Nias Gunungsitoli.

\section{KESIMPULAN \& SARAN}

Dari hasil pengujian setiap butir item pertanyaan untuk variabel $\mathrm{X}$ dan $\mathrm{Y}$ maka diperoleh item pertanyaan tersebut semuanya valid dimana nilai $r$ hitung lebih besar dari $r$ tabel $(0,404)$. Sedangkan dari hasil uji reliabilitas dimana untuk variabel $\mathrm{X}$ diperoleh $r_{i i}=0,759>r$ tabel $=0,404$ dan untuk variabel $Y$ diperoleh $r_{i i}=0,515>r$ tabel 0,404, maka seluruh item pertanyaan dinyatakan reliabel. Selain itu, diperoleh nilai korelasi antara variabel X (Media Sosial) dengan Variabel Y (Keputusan Pembelian) sebesar $r_{i i}$ $=0,4085$. Ini berarti bahwa variabel $\mathrm{X}$ dan $\mathrm{Y}$ memiliki korelasi diman rii $>$ rtabel atau $0,4085>0,404$. Sementara dari hasil pengujian hipotesis dengan menggunakan uji $t$ dengan jumlah $\mathrm{n}=24$ pada tingkat kepercayaan 95\% diperoleh nilai $\mathrm{t}_{\text {tabel }}$ sebesar 2,0738. Berdasarkan ketentuan yang berlaku, jika $t_{\text {hitung }}>t_{\text {tabel }}$ atau 2,0991>2,0738 
maka Ha ( Hipotesis Alternatif) diterima dan Ho ditolak. Dengan demikian dapat dinyatakan bahwa terdapat pengaruh Media Sosial terhadap Keputusan Pembelian di Toko Kaos Nias Gunungsitoli.

Saran yang disampaikan setelah dilakukannya penelitian ini, hendaknya pengelola toko Kaos Nias melakukan pelayanan prima dalam melayani kebutuhan konsumen dan mempertahankan respon konsumen pada kegiatan pemasarannya serta terus melakukan promosi dengan menggunakan media sosial.

\section{DAFTAR PUSTAKA}

Arikunto. (2015). Prosedur Penelitian Suatu Pendekatan dan Praktik. Jakarta: Rineka Cipta.

Andreas, Kaplan M. Haenlein Michael. (2014). Users of the world, unite! The challenges and opportunities of social media. Business Horizons 53. (1). P. 61

Basu Swastha. (2015). Manajemen Pemasaran Modern. Jakarta : Liberty

Howard, P.N., Parks,M.R. (2012). American Behavioral Scientist, Vol. 45 No. 3.

Kanuk. (2000). Perilaku Konsumen. Edisi 1. Jakarta: Indeks Gramedia.

Keller, K. Lane. (2016). Strategi Bauran Pemasaran. Jakarta : Indeks

Kotler, (2015). Manajemen Pemasaran Edisi Milenium. Jakarta : PT. Prehalindo

Lamb Jr, Hair Jr, Mc Daniel. (2013). Pemasaran. Terjemahan David Oktaveria. Jakarta : Salemba Empat.

McQuail, Denis. (2011). Teori Komunikasi. Jakarta : Salemba Empat.

Morrison. (2007). Intructional Quality Indicator. Cambridge : Research Foundation

Nasrullah, Rulli. (2015). Media Sosial Perspektif Komunikasi, Budaya dan Sosioteknologi. Bandung : Simbiosa Rekatama Media.

http://www.apjii.or.id. 